\title{
The Educational Turn in Contemporary Art and Critical Aesthetic Pedagogy: Rethinking the Theory of Aesthetic Education
}

\begin{abstract}
The article presents the two phenomena observed in the space of art and education in $21^{\text {st }}$ century, which may constitute the basis for rethinking and modernizing the theory of aesthetic education. The first is the educational turn in contemporary art, consisting in the use of pedagogical methods and forms by artists in their creative work. Education becomes not only the subject of contemporary artistic projects, but above all, an artistic practice, the foundations of which were taken from radical pedagogy. The second element important for rethinking the theory of aesthetic education is the perspective of critical pedagogy. The article briefly presents Yolanda Medina's Critical Aesthetic Pedagogy, which tries to combine aesthetic pedagogy with a critical approach in the context of self and social empowerment. New ways of intertwining the spheres of art and education in the $21^{\text {st }}$ century may be an opportunity to renew and modernize both the practice and theory of aesthetic education, and to strengthen the aesthetic education approach in Polish pedagogy.

Keywords:

aesthetic education, educational turn, critical pedagogy, art education, contemporary art
\end{abstract}

\section{INTRODUCTION}

The relationship between art and education has been in the area of pedagogical interest for a long time. The Polish School of Aesthetic Education crystallized in

1 Aesthetic Education and Cultural Studies Unit, Faculty of Education, University of Warsaw, Poland.

E-MAIL: b.kwiatkowska@uw.edu.pl ORCID: 0000-0002-8927-8943 
the 1960s and 1970s, but its sources date back to the beginning of the $20^{\text {th }}$ century, when the belief in the possibility of shaping a better person by art went hand in hand with the belief in the possibility of creating a better world. The thought of Janina Mortkowiczowa, Stefan Szuman, Stanisław Ossowski and Bogdan Suchodolski found a continuation in the theory of aesthetic education, which was finally shaped by Irena Wojnar. In the $21^{\text {st }}$ century, the theory of aesthetic education has to deal with critical voices towards the traditional understanding of aesthetic education. We can hear accusations that pedagogy has its own concept of culture and art, delineated by tradition, creating a separate ideological and axiological option, "frozen" in pedagogical knowledge, thus limiting the discourse and depriving us of the possibility of answering questions, which are important in the perspective of the contemporary cultural landscape (Moszkowicz, 2005, p. 22). Narrow understanding of aesthetic education as an introduction to the accumulated cultural goods and values causes this sort of education to be perceived as a disciplining force that requires internal obedience. On the one hand, it begins to be perceived as a compulsion, imposing certain interpretations and behaviors. On the other hand, it is associated with the domain of elite, a kind of luxury, an addition to life focused on raising the social position. Aesthetic education is sometimes seen as a specific cultural regulation, indicating a specific, "planned” repertoire of canonical knowledge to be mastered in order to obtain a "proper" attitude to life. The above-mentioned critical voices towards aesthetic education, changes in contemporary art and a certain incompatibility of the pedagogical understanding of art with contemporary trends in the art world, have resulted in gradual decline of the position of aesthetic education in the pedagogical community itself and in more and more frequent accusations of the stagnation of scientific reflection on aesthetic education (Zalewska-Pawlak, 2017, p. 138). However, it is worth noting that at the same time when the importance of aesthetic education in the pedagogical society (at least in the Polish context) is declining, a completely different tendency is noticeable in the art world. I would like to present two phenomena, which could be useful for rethinking and "updating” the Polish theory of aesthetic education.

\section{CRIticAl PEDAgOgy PERSPECTIVE}

In the recent years we have noticed intense discussions on the educational turn in contemporary art, the increased interest on participatory, intervention and community strategies in the activities of contemporary artists and the issues of 
function and social effectiveness of art. The active participants in this debate are also educators, especially those who focus their pedagogical activity on the space of art. The emerging educational and social themes and methods in the artistic work of contemporary artists open up opportunities for effective and creative cooperation between the artistic and pedagogical communities, not only in the form of discussions on the educational functions of art, but in practice of co-creating and co-implementing artistic and educational projects that are happening at the point of contact of art and pedagogy, "post-artistic" activities, which are outside the field of art: an artistic experiment that crosses the boundaries of the field of art, operating through porosity, permeability and hybridity of art (Szreder, 2018, p. 31). However, the vision of such cooperation requires from art educators to go beyond the area of considerations connected with the narrowly understood theory of aesthetic education, to extend the issue of education through art to contemporary interpretive contexts of art. It is also worth considering the reinterpretation of the pedagogical concept of art and its scopes due to the dynamically changing cultural and social reality (Zalewska-Pawlak, 2017, p. 57). The theory of aesthetic education has an extremely noble educational character, which still remains valid in many aspects, but in the context of contemporary changes in art and culture, the existing assumptions of aesthetic education require some revision and reinterpretation (Pankowska, 2013, p. 170). Krystyna Pankowska emphasizes that nowadays aesthetic education should be multifaceted and multitasking, in the context of three time dimensions: the past (turning to ancient art that encodes a permanent human condition), the present (educational contexts of contemporary art and popular culture - shifting the focus to shaping critical awareness), and the future (virtual space and new media as a new democratic opportunity for aesthetic education) (Pankowska, 2013, p. 179). Taking into account, on the one hand, the rich tradition of education through art and the need to reinterpret the theory of aesthetic education signaled by Pankowska, and, on the other hand, very carefully following what is happening in the contemporary art, we can notice another pedagogical perspective useful for the analysis of the art-education relationship: the perspective of critical pedagogy.

Critical pedagogy, which presents the universal problem of the criticality of discourse and educational activity, understands education as one of the basic areas of the struggle for a more just and egalitarian society of tomorrow. It treats schools as a place of critical education in which the ability to "rule one's life" is acquired by controlling the processes of creating and acquiring knowledge (McLaren, 1998; Giroux \& Witkowski, 2010). The task of education is to raise the level of social awareness, and thus influence the quality of the civic community, which 
will result in the emergence of new social movements actively opposing the current state of injustice and inequality. An important element of such education is language that allows for an open exchange of ideas, dialogue, and expression of individual and social freedom. This educational perspective avoids describing the world in a pre-imposed way that follows one pattern, one ruling discourse that makes it impossible to express what is accidental, historically variable, "everyday" and private (Szkudlarek \& Śliwerski, 1992, pp. 77-78). At the heart of pedagogy understood in this way is the question of difference, voice, resistance, the fight against inequality, the extension of basic human rights, etc. The school and the classroom are spaces where various interests clash. It is a space that is not free from discrimination, inequality and prejudice. Critical pedagogy aims to make aware all subjects of the educational process: teachers, students and parents, that this seemingly neutral space has never been and never will be neutral (McLaren, 1998, p. 20). Critical pedagogy, respecting the rights of individuals and social groups to decide about themselves, resigns from forming the pupil in accordance with the adopted model, and perceives its role in creating a space in which it becomes possible to "suspend" the naturalness of meanings and "neutrality" of the binding definitions of the surrounding world. Critical orientation in pedagogy prompts reflection on the presence of some meanings, and the "silencing" of other meanings in contemporary culture, exposes the myths and illusions of the official public sphere, reflects on the situation of cultural oppression and the inaudibility of the voices of some subjects. The critical concept of the pedagogical voice, articulating one's own interests and expressing one's own vision of the world, thus showing the multiplicity and diversity of voices present in the world, seems very close to the actions of contemporary artists. Henry A. Giroux's and Peter McLaren's pedagogy opens up the horizons of education for critical discourse in the public sphere. This requires critical literacy in all forms and at all levels of formal and informal education. A special place for contemporary art in the educational space is visible in this critical literacy postulated by Giroux and in shaping competences for active social action ("active citizenship”). This is the point where an educational space opens up for critical aesthetic education.

\section{CRItical AESthetic PEDAgOgy}

The inclusion of considerations on the relationship between art and politics to the pedagogical discourse, the analysis of the tasks of socially engaged art with its community-building potential, giving people agency by changing the ways of 
communicating and acting, fits in the interests of critical educators. The strategy of critical educators, consisting in actions allowing people to be competent in using their own voice - the concept of a pedagogical voice (Giroux, 1994), articulating their interests, expressing their own vision of the world, thus showing the multiplicity and diversity of attitudes and views present in the world, seems to be very close to the activities of contemporary artists, especially those creating socially engaged art. The analysis of the potential of art through the prism of critical pedagogy allows for the inclusion of those areas in the considerations on the art-pedagogy relationship, those areas that did not appear in the discourse on education through art, conducted on the basis of cultural pedagogy or the theory of aesthetic education (Kwiatkowska-Tybulewicz, 2016, pp. 16-23). When we are thinking about critical aesthetic education, the following issues come to the fore, such as: critical awareness, social change, importance of personal experience, democratic model of education, inclusion, dialogue, accepting the difference, awareness of a sense of agency. Critical pedagogy could direct aesthetic education more towards flexibility, changes, everyday experiences and knowledge, and fallibility, "which can be understood as a form of knowledge production rather than one of disappointment" (Rogoff, 2008, p. 7). It is not that the above-mentioned elements are completely absent in the theory of aesthetic education (as evidence one can mention the matter of experience in Dewey's concept, strongly present in the theory of aesthetic education), but the theory of aesthetic education does not particularly emphasize these elements.

In looking for ways to incorporate a critical approach into the theory of aesthetic education, it could be useful to analyze the concept of Critical Aesthetic Pedagogy (CAP), formulated by Yolanda Medina. In her book Critical Aesthetic Pedagogy: Toward a Theory of Self and Social Empowerment (2012), Medina describes the fusion of a pedagogical and a philosophical approaches: critical pedagogy and aesthetics, in order to promote the infusion of a particular type of aesthetic experience into critical educational practices (Medina, 2012, p. 28). Critical Aesthetic Pedagogy is, according to her, a method by which the students might become empowered to progress from being aware of the need for social change to enacting it. She is largely inspired by the practice and thoughts of Paulo Freire, Peter McLaren, Maxine Greene and Jill Green. Medina emphasizes three crucial elements of critical pedagogy, which provide the foundation of CAP. The first is treatment of personal experiences as the most important educational tool. The classroom is a space where students feel safe to share their personal experiences. The second is the challenge to existing conservative model of schooling, where teacher functions as knowledge provider and students passively absorb the 
information. The dominant pedagogical system is hierarchical and non-interactive. As Medina explains: "This educational model reinforces dominant system because it discourages critical and independent thinking and gives teachers absolute power to decide which information is most important” (Medina, 2012, p. 28). In her opinion, Critical Aesthetic Pedagogy clearly deviates from this conservative type of thinking and educational methods. The third important element in her concept is encouraging students to explore how their experiences shape their identities and how they are shaped by the culture in which they live. In other words, from educational perspective it is very important to make critical analysis of cultural identity and its influences (Medina, 2012, p. 28).

By developing these three bases which the author has incorporated from critical pedagogy into aesthetic pedagogy, Medina draws attention to other important elements of CAP. She emphasizes the importance of democratic ideals, because it assures all students the fundamental right to participate and to be heard (at this point, it is worth recalling the concept of pedagogical voice, which was important for Giroux). The author claims that "Critical Aesthetic Pedagogy borrows this ideal from critical pedagogy and encourages a form of education that is inclusive, holistic, and multicultural in every regard” (Medina, 2012, p. 29). Medina accentuates that every student in the classroom comes with different kinds of knowledge, experiences and consciousness, which shape the ways they see the world and in which they learn. "It is the critical aesthetic educators' responsibility to meet each student's needs by connecting the learning process to the culture in which they have learned how to learn” (Medina, 2012, p. 29). Students learn by employing the knowledge they bring into the classroom. Integrating their experience to the learning process allows students to personalize the knowledge and produce their own knowledge which is relevant to their lives. It is worth to mention that in CAP the teacher's personal experience is important too and it is possible to include it to academic discussion. Medina explains: "In this way, teachers can be seen as whole human beings who exist outside the classroom walls, with complex lives in which they love, care, and struggle for meaning” (Medina, 2012, p. 30). The author notices that today's dominant educational model is characterized by a lack of relevance. This learning process discourages students from becoming active and involved participants in their own educational process and then in their lives. They become passive recipients of sets of information which discourage their critical analysis and relevant meaning, because both can be created when we relate our personal knowledge to the new information we receive. As Paulo Freire said: “The more students work at storing the deposits entrusted to them, the less they develop the critical consciousness which would result from their intervention in the world 
as transformers of that world" (Freire, 2000, p. 73). In CAP, students learn to analyze new information using their accumulated life experience.

Critical pedagogy underlines the importance of diversity, difference between people, validity of all voices, otherness not as a threat, but as a potential. In CAP, noticing and appreciating the differences is essential. Medina says that when educators treat curricula as "color blind" (or create "color blind" curricula), the students' authentic voices are eliminated from the conversation, and the educator remains the only legitimate source of knowledge (Medina, 2012, p. 32). When we look at the contemporary text about aesthetic education on a Polish basis, we can see that this kind of thinking about aesthetic education is still dominant (although it is slowly changing). Critical Aesthetic Pedagogy creates a classroom environment in which all differences (class, culture, language, economy, gender differences) are used constructively and students exist primarily as human beings and all differences are accepted, valued and encouraged (Medina, 2012, p. 34).

Critical Aesthetic Pedagogy helps students to recognize the existence of their allegiances and subordinations. They have possibility to take into consideration the problem of influence and shaping the identity by dominant ideologies in culture in which they live. "Central to the work of Critical Aesthetic Pedagogy is the belief that when individuals become aware of how their allegiances perpetuate oppression, they will develop critical voices that can help them discuss system of domination and notions of justice” (Medina, 2012, p. 37). The most important is to help the students become more aware of issues of oppression and privilege, and the need to create social changes. Medina, during her educational practice, realized that critical pedagogy neglects some elements that are indispensable for the empowerment of students to create social change. According to Medina, students must be able to use their bodies as mediators in interactions with artwork. However, pedagogical practice of CAP treats the body as the site where identity is shaped, manipulated and marked by culture. "While critical pedagogy may help develop students' critical awareness, it falls short of empowering them to create social change, because it ignores the body as a primary site for shaping knowledge” (Medina, 2012, p. 40). Medina writes about body authority as a visceral feeling that helps us distinguish what is fair from what is unfair (Medina, 2012, p. 40). She thinks that students' disconnection from their body authority hinders their capacity to imagine. She realised that although her students were aware of oppression and they understood the need for change, they still felt powerless to create these changes because they had a problem with imagining the future. She alludes to Maxine Greene’s definition of imagination as “ability to look at things as if they could be otherwise" (Greene, 1995, p. 19). The author underlines two 
elements that can be taken into account in developing a successful CAP: 1. Imagination illuminates the path toward possibilities. 2. Compassion gives us the desire to embark on the path toward change (Medina, 2012, pp. 42-43). This employment of the body as a source of emotional authority and a mediator of compassion is the unique contribution of Critical Aesthetic Pedagogy.

One more aspect of Medina's CAP could be interesting for the contemporary theory of aesthetic education. She stops longer at Susan Stinson's three levels of aesthetic experience (Stinson, 1985). Stinson's levels provide a structure for comprehension of how encounters with art might already be used in schools and how they can be used as educational tools to strengthen students empowerment. At the first level of aesthetic experience there is appreciation of the beauty of the artwork. This first level cannot release the imagination or compassion in the observer because the artwork has not got any connection with their previous experience. Medina notes that this way of using art in education is analogous to the "banking method of education" as described by Freire (2000, p. 73), when students do not have possibility to apply critical thought or individual and subjective interpretation or assessment. At the same time she sadly states that this kind of aesthetic experience is offered in school in conventional art education. When we look at the Polish aesthetic education we could notice that this level of theoretical reflection is present in many texts about the educational aspects of art. Stinson's second level concerns the way in which the work of art moves the recipient. The effect of this relationship depends on relevant personal experiences which are brought by observer into the artistic encounter. "Some will describe this level of experience as a transcendental moment in which they discover their connection to their own body authority, and this kind of primal reconnection can give people the strength and security to create positive change in their lives” (Medina, 2012, p. 45). In Medina's opinion, the second level can release the imagination and allow the observer to see their future better life, but it does not encourage them to going beyond the personal sphere, into the social realm (Medina, 2012, p. 46). Only the third level of aesthetic experience strengthens the relationship between the observer and the world around him. This is the time when we can move from personal sphere to social sphere. It concerns particularly this sort of art which encourages that sharing of experiences of suffering and oppression is a vehicle for recognition of common sources of oppression. The author believes that students must be able to use their bodies as mediators in interactions with artwork: "This participatory encounters with works of art should involve the body as a mediator of experience and employ its language to explore the work of art, because this is the only way in which we can truly appreciate the human emotions that are 
represented in the work” (Medina, 2012, p. 46). In the third level we could explore our potential to bring about change, because it reconnects us to our body authority, which is the source of self and social empowerment (Medina, 2012, p. 47). The movement from self to social empowerment and the infusion of aesthetic experience into a social justice is the characteristic element of Medina's thought. The aim of Critical Aesthetic Education can be understood as creating this type of aesthetic experience in an educational context.

\section{THE EDUCATIONAL TURN IN CONTEMPORARY ART}

As it was mentioned earlier in this article, at a time when there were more and more critical voices against the theory of aesthetic education and accusations of stagnation of scientific reflection on aesthetic education in Poland, in the sphere of art the relationship between art and pedagogy entered a new path. In the $21^{\text {st }}$ century, the art world became fascinated by education and pedagogy. This phenomenon was named the educational turn in contemporary art. The first sources of this phenomenon can be found in Russian constructivists, the Bauhaus and the faculty of Black Mountain College. They tried to annihilate distinction between art and life using educational instruments, but they did not appropriate pedagogical forms in their artistic works. Pedagogical elements were used only as a means to an end (Podesva, 2007). Precursors of contemporary artists working on the edge of art and pedagogy are: Luis Camnitzer, Lygia Clark, Jef Geys, Tim Rollins, and Joseph Beuys. The last one said that "to be a teacher is my greatest work of art" (Bishop, 2012, p. 243). Beuys and his practise in the 1970s is treated as the next step towards the current educational turn. From 1971, the German artist presented educational lectures as performances, documented in a series of photographs and blackboard drawings which register the artist's actions (Podesva, 2007). His lectures and seminars were dedicated to social, cultural and political issues. In February 1972, he ran performative lectures in Tate and Whitechapel Gallery. In the same year he installed an office of the "Organization for Direct Democracy by Referendum" during Documenta 5, where he discussed with the audience on a range of topics including politics and art. The school boards with the traces of these performative discussions have become installations, which were shown in exhibition spaces as a symbol of social and intellectual exchange (Bishop, 2012, p. 243). Education was very important issue for this artist. This is evidenced by the establishment of the Free International University (FIU) for Creativity and Interdisciplinary Research - a school outside the academic system, operating from 1973 until the mid-90s. 
FIU was the place where his educational ideas were implemented. It was a free and open school, which offered students an interdisciplinary and comprehensive study program, based on art, cultural studies, sociology, anthropology and economic. Beuys invited a lot of interesting artists, scientists and intellectuals to produce with the students a creative and free space for discussions, workshops and seminars. Looking at Beuys' actions from the pedagogue's perspective, one of the most important projects was "100 Days of the Free International University”, which was organized during Documenta 6 in 1977. In thirteen interdisciplinary and open for the audience workshops participated artists, musicians, actors but also sociologists, politicians, scientists, activists and other guests. Beuys created the extended concept of art and thus announced a topic which is important for today's educational turn in contemporary art (Kwiatkowska-Tybulewicz, 2018, p. 71).

Artistic experiments with educational nature have become more frequent recently. The educational turn in $21^{\text {st }}$ century produces numerous exhibitions, books and artistic initiatives devoted to education. Contemporary artists reach for pedagogical forms of activities, e.g., workshops, discussions, lessons, lectures, seminars, reading rooms, libraries, publications, etc., which are treated as the form of art. As Claire Bishop emphasizes in her book Artificial Hells (2012), in the $21^{\text {st }}$ century, we are witnesses of a clearly visible increase in number of artisticpedagogical projects undertaken by artists. More and more artists and curators are involved in projects that appreciate forms and methods from the educational sphere. The projects of Tania Bruguera, Paul Chan, Paweł Althamer and Thomas Hirschhorn clearly indicate the educational turn in the contemporary art. Education is becoming interesting for the "art world". However, it must be clearly emphasized that the artistic activities which are related to the educational turn do not only take education as a theme, but rather they operate as an expanded educational praxis (O’Neill \& Wilson, 2010, p. 12).

The term ‘educational turn' gained prominence in Irit Rogoff's article “Turning” which was published in e-flux journal in 2008 (Rogoff, 2008). This turn provided a critique of the idea of education "as one-directional knowledge transfer and training, and the framing of education as a commercialised industry, reduced to the utilitarianism of training for working life” (Graham, Graziano, \& Kelly, 2016, p. 29). The artistic projects which are part of the educational turn refer to radical pedagogy and alternative teaching and learning. In these artistic projects there can be seen views of Paulo Freire's Pedagogy of the Oppressed (2000), which was first published in English in 1970, Ivan Illich's Deschooling Society (1971), Jacques Rancière's The Ignorant Schoolmaster (1991), or Augusto Boal's The Theatre of the Oppressed (1979). The artists focus on the alternative forms of knowledge 
production, empowerment of viewers/participants/students, giving them a sense of agency, which is important not only in art but above all in life. These new works in the field of art are a specific combination of educational and artistic activities. Sometimes they take the form of special temporary schools run by artists, symposia, lectures and seminars series, where the students can discuss, act and become aware of the modern world and the mechanisms that influence them, but also enrich their own personality and skills. In context of the educational turn, the following initiatives are worth mentioning: Copenhagen Free University (2001), Playshop (2004), Momentary Academy (2005), the School of Panamerican Unrest (2006-2007), Manifesta 6 Art School in Nicosia (2006), the exhibition series: Academy: Learning from Art/Learning from the Museum at the Van Abbemuseum, Eindhoven, and MuHKA, Antwerp (2006), Manifesta 8 Murcia (2010), the $6^{\text {th }}$ and $8^{\text {th }}$ Mercosul Biennials (2007, 2011), the $30^{\text {th }}$ Biennial of Sao Paulo (2012), Documenta 13 and 14 in Kassel $(2012,2017)$ and other numerous curatorial initiatives, exhibitions, books and artistic activities that devoted considerable space to themes of education. Kristina Lee Podesva (2007), based on her own research into a few art projects that take educational forms as their medium, indicated their characteristic elements, which include the following:

1. A school structure that operates as a social medium.

2. A dependence on collaborative production.

3. A tendency toward process-based (versus object-based) production.

4. An aleatory or open nature.

5. An ongoing and potentially endless temporality.

6. A free space for learning.

7. A post-hierarchical learning environment where there are no teachers, just co-participants.

8. A preference for exploratory, experimental, and multidisciplinary approaches to knowledge production.

9. An awareness of the instrumentalization of the academy.

10. A virtual space for the communication and distribution of ideas.

The educational turn is significant not only from the perspective of traditional mission of art education and aesthetic education (producing the audience for art, shaping aesthetic sensitivity, education through beauty, etc.), but as a form of production of public discourse, a force that encourages changes, a force that gives a sense of agency, and the sphere in which the activity is carried out with (not for or about) the audience. As Paul O’Neill and Mick Wilson emphasize (2010, p. 12), 
discussions, talks, educational programs, debates and discursive practices have long played a supporting role to the exhibition of contemporary art. But nowadays these discursive interventions have become the main event.

However, these discursive productions are not only pervasive; increasingly, they are framed in terms of education, research, knowledge production and learning. [...] [They] often implement a durational dialogical process, along the informal lines of Socratic elenchus rather than prescriptive 'schooling' or 'explication'. In other words, they seem to seek not the masterful production of expertise and the authoritative pronouncement of truth but rather the coproduction of question, ambiguity and enquiry, often determined by the simple contingencies of where people happen to begin a conversation (O’Neill \& Wilson, 2010, pp. 12, 13-14).

This is a new way of treating education as art and a new perspective of cooperation between artists and educators.

\section{SUMMARY}

The theory of aesthetic education has a long tradition in Poland. Its contribution to the pedagogical thought in the $20^{\text {th }}$ century cannot be underestimated. It is worth remembering about its advantages, and not just focusing on the assumption that could be problematic from today's perspective. However, the landscape of art and aesthetic education in the world is changing due to the expanding field of art and new educational, social and cultural challenges in the $21^{\text {st }}$ century. It requires a refreshing view of the theory of aesthetic education (and also the practice in this field). The two phenomena which were presented in this article (the educational turn in contemporary art and Critical Aesthetic Pedagogy) can constitute a significant inspiration for today's considerations of the relationship between art and pedagogy and the basis for rethinking of theory of aesthetic education. The currently observed educational turn in contemporary art is a great opportunity for the pedagogical community (especially for pedagogues connected with aesthetic and art education) to emphasize the importance of pedagogical activities in the field of art and thus restoring the importance of aesthetic and art education not only in school practice but also in academic discussion and social space. The perspective of critical pedagogy can be refreshing, inspiring and useful in this case. Although it may seem difficult to find points of contact between cultural pedagogy (which was the basis of theory of aesthetic education) and critical pedagogy, it is worth bearing in mind how Peter McLaren defined culture as "a set of practices, ideologies, and values from which different groups draw to make sense of the world” 
(McLaren, 1998, p. 200). It is also worth to remember about Pankowska's remark that theory of aesthetic education was created in cultural and educational space with clearly delineated aesthetic and ethic boundaries. In the context of contemporary culture, education (as well as education through art) becomes a much more difficult task than in the perspective of fundamentalist pedagogy, which referred to strictly defined contents and principles (Pankowska, 2013, p. 178). Now we are living in different century and different circumstances.

The importance of art in pedagogical and educational sphere is obvious for us (pedagogues involved in aesthetic and art education). The situation that the artistic society is becoming aware of the power of education is reassuring. At the beginning of the current century we could notice a lot of discussions taking place in "the art world" concerning the issue: can art cause change? The educational turn could be understood as the answer to this question: yes, but in cooperation with education. The art space has the ideas, imagination, creation, the power of resistance. Sometimes it could be visible that artists want to influence people (encourage them to change) through their art but they reach the "glass ceiling". The situation in educational sphere is opposite. Education has power to influence people, but in majority it is too conservative, embedded in the structures of power, discipline, coercion and subordinated to economic values. Education in the $21^{\text {st }}$ century is mostly characterized by commoditization, over-bureaucratization, ever-increasing emphasis on predictable outcomes, etc. (Rogoff, 2008, p. 5). The interweaving of the spheres of art and education therefore seems to be beneficial for both of them. It can only be sad (and a little embarrassing for pedagogical society) that the contemporary artists are leaning towards these models of education that have been known in pedagogy for at least half a century (or even longer taking into account the New Education movement), but they were marginalized. Nevertheless, it also gives some hope for the expected changes in education, to which we, as pedagogues, can also contribute with the support of artists. It is worth to emphasize that Irena Wojnar, creating the theory of aesthetic education in 1960s, already noticed that "education through art can overcome the mistakes of traditional education and that is why it is often called as education for the future" (Wojnar, 1964, p. 239). Looking at a cooperation between art and education as an opportunity to change the traditional model of education is not therefore a new element. Today's strong presence of (alternative) education in the field of art could in the future contribute to refreshing of the current dominant model of education in society. Let it be so... 


\section{References}

Bishop, C. (2012). Artificial Hells: Participatory Art and the Politics of Spectatorship. London-New York: Verso.

Boal, A. (1979). The Theatre of the Oppressed. London: Pluto Press.

Freire, P. (2000). Pedagogy of the Oppressed (30 ${ }^{\text {th }}$ Anniv. Ed.). New York: Continuum.

Giroux, H.A. (1994). Wobec wyzwań tożsamości i różnicy (poza dyskurs edukacji wielokulturowej). In: J. Brzeziński, \& L. Witkowski (Eds.), Edukacja wobec zmiany społecznej (pp. 411-434). Poznań-Toruń: Wydawnictwo Edytor.

Giroux, H.A., \& Witkowski, L. (2010). Edukacja i sfera publiczna. Idee i doświadczenia pedagogiki radykalnej. Kraków: Oficyna Wydawnicza Impuls.

Graham, J., Graziano, V., \& Kelly, S. (2016). The Educational Turn in Art: Rewriting the Hidden Curriculum. Performance Research, 21(6), pp. 29-35. DOI: 10.1080/13528165. 2016.1239912.

Greene, M. (1995). Releasing the Imagination: Essays on Education, the Arts, and Social Change. San Francisco, CA: Jossey-Bass.

Illich, I. (1971). Deschooling Society. New York: Harper and Row.

Kwiatkowska-Tybulewicz, B. (2016). Wychowawcze aspekty sztuki współczesnej. Z perspektywy pedagogiki krytycznej. Warszawa: Wydawnictwa Uniwersytetu Warszawskiego.

Kwiatkowska-Tybulewicz, B. (2018). All Human Questions Can Only Be Questions about Creation: The Extended Concept of Art by Joseph Beuys as an Inspiration for Education in the Field of Art. Spirituality of a Personality: Methodology, Theory and Practice, 2(83), pp. 64-74.

McLaren, P. (1998). Life in Schools: An Introduction to Critical Pedagogy in the Foundations of Education (3 ${ }^{\text {rd }}$ Ed.). New York: Longman.

Medina, Y. (2012). Critical Aesthetic Pedagogy: Toward a Theory of Self and Social Empowerment. New York: Peter Lang.

Moszkowicz, M. (2005). Edukacja artystyczna w epoce estetyzacji i anestetyzacji. In: W. Limont, \& K. Nielek-Zawadzka (Eds.), Dylematy edukacji artystycznej. Vol. 1: Edukacja artystyczna wobec przemian w kulturze (pp. 21-38). Kraków: Oficyna Wydawnicza Impuls.

O'Neill, P., \& Wilson, M. (Eds.) (2010). Curating and the Educational Turn. London, Amsterdam: Open Editions and de Appel.

Pankowska, K. (2013). Kultura - sztuka - edukacja w świecie zmian. Refleksje antropologiczno-pedagogiczne. Warszawa: Wydawnictwa Uniwersytetu Warszawskiego.

Podesva, K.L. (2007, Summer). A Pedagogical Turn: Brief Notes on Education as Art. Fillip, 6. Retrieved from: https://fillip.ca/content/a-pedagogical-turn (access date: 7.07.2020).

Rancière, J. (1991). The Ignorant Schoolmaster: Five Lessons in Intellectual Emancipation. Stanford University Press.

Rogoff, I. (2008, November). Turning. e-flux journal, 11. Retrieved from: https://www.e-flux. com/journal/00/68470/turning/ (access date: 7.07.2020).

Stinson, S. (1985). Curriculum and the Morality of Aesthetics. Journal of Curriculum Theorizing, 6, pp. 66-83.

Szkudlarek, T., \& Śliwerski, B. (1992). Wyzwania pedagogiki krytycznej i antypedagogiki. Kraków: Oficyna Wydawnicza Impuls. 
Szreder, K. (2018). Konkret a sprawa polska. Parę słów przypomnienia o nadwiślańskich debatach wokół niebezpiecznych związków sztuki i polityki. In: steirischer herbst \& F. Malzacher (Eds.), Prawda jest konkretna. Artystyczne strategie w polityce. Podręcznik (pp. 26-31). Warszawa: Fundacja Nowej Kultury Bęc Zmiana.

Wojnar, I. (1964). Estetyka i wychowanie. Warszawa: Państwowe Wydawnictwo Naukowe.

Zalewska-Pawlak, M. (2017). Sztuka i wychowanie w XXI wieku. Łódź: Wydawnictwo Uniwersytetu Łódzkiego. 